\title{
Physical separation for upgradation of valuable minerals: a study on sands of the Someswari river
}

\author{
M. A. Rahman, M. N. Zaman, P. K. Biswas, S. Sultana and P. K. Nandy \\ Institute of Mining, Mineralogy and Metallurgy, Bangladesh Council of Scientific and Industrial Research, Science \\ Laboratory Road, Khonjonpur, Joypurhat 5900, Bangladesh.
}

\begin{abstract}
The study is carried out to develop a physical separation method for upgradation of valuable minerals from sands of the Someswari River. Understanding the morphology and mineralogy of the heavy minerals may allow development of processing methods that produce the higher grade products. For this purpose, grain size analysis, microscopic, spectroscopic study and feasibility of physical separation by shaking table, electrostatic plate separator and induced roll magnetic separator have been done. Considering the huge quantity of sandy materials of the studied river sands and separation of heavy minerals magnetite, ilmenite and garnet from the bulk sands and further treatment of the light mineral quartz to remove iron coating could be use as glass-sands; either the light mineral quartz or heavy minerals will be the main product. From the overall study by physical separation method, the Someswari River is identified as potential resources for mineral processing.
\end{abstract}

Keywords: Mineral processing; Physical separation; Someswari; Quartz; Ilmenite

\section{Introduction}

Physical separation is the mainstay of industrial minerals processing. It is traditionally defined as the separation of minerals or materials by exploiting the differences in their physical characteristics, such as specific gravity, magnetic susceptibility and/or electrical conductivity. Physical separation methods are generally cost effective, with regard to both capital and operating costs. Power requirements typically involve slurry pumping for gravity systems, and small motors to turn the rolls and drums used in magnetic and electrostatic separators. As reagents are seldom used, operation costs and environmental concerns are also reduced (Elder, 2006).

As with most mineral industries, with time the easier and higher quality deposits become depleted. Remaining deposits may be smaller, more isol ated, deeper, slime-enriched dominated by fine minerals or suffer from other challenges. This may also be true with older operations struggling to feed concentrators. As many mineral sands deposits are in coastal areas, competing land use restrictions are often limiting factors. In fact, all operations will suffer from resource depletion at some time and declining grades are a fact of life. In other cases, as mines are depleted the new deposits being considered for development are often poorer quality opportunities than what was considered in the past (Elder and Kow, 2005).
The Someswari River sand deposit which is studied in this research is located in the north eastern part of Bangladesh. Someswari River known as Simsang River in the Indian state of Meghalaya, is a major river in the Garo Hills of Meghalaya and Netrakona District of Bangladesh. It divides the Garo Hills into two parts. According to west Garo Hills district profile by State Government of Meghalaya, the Tura range is the source of the River, one of the major rivers of Meghalaya. The Someswari River is the largest and the second longest river in West Garo Hills District, India. The river is locally known as Simsang. It starts from Nokrek Mountains and runs towards the east, passing through Williamnagar, Nongalbibra, Siju, Rewak and lastly Baghmara. The upper course of this river is not navigable however the lower course has many deep pools and falls. They are Mirik, Matma, Jamiseng, Warisik, Bobra, Goka, etc. The chief tributaries are Chibok, Rongdik, Rompa and Ringdi rivers. It enters into Bangladesh through north eastern part near Bijoypur area of Netrokona district (Fig. 1).

Mineral processing from sands is a profitable business in some countries (e.g. Australia, China, Indonesia, India etc.) in the world, as these minerals are used in many important industries particularly in the developed countries. Over the years the bulk of production has been exported in the form of raw concentrates to the more advanced economics for

*Corresponding author: aminur08@gmail.com 
processing and consumption. However, increased sensitivity to negative aspects of environmental problems and pollution associated with the industry, the location of relatively cheap power sources, and national aspirations in the developing countries are opening up new opportunities for processing of mineral concentrates before export (Anomymous, 1991).

The Someswari River of Bangladesh is mainly sand bedded rivers and the quantity of sediments carried by these rivers is tremendous and the sediments contain large quantity of sandy materials, which are generally laid down in the beds of the river, forming sand bars. The main objective of this study is to utilize the huge amount of sand of the river by developing a physical separation method of mineral processing for separation of valuable heavy and light minerals economically. The samples were collected in between $25^{\circ} 10^{\prime} 27.6^{\prime \prime} \mathrm{N}-90^{\circ} 39^{\prime} 35.6^{\prime \prime} \mathrm{E}$ to $25^{\circ} 06^{\prime} 13.9^{\prime \prime} \mathrm{N}-90^{\circ} 40^{\prime} 55.9^{\prime \prime} \mathrm{E}$. The main objectives of the present study are

- To characterize the sand of someswari river

- To conduct physical separation test on the sand of Someswari River for upgrdation heavy mineral in the samples

- Characterization of the separated fractions

\section{Materials and methods}

The samples were randomly collected from the sand bar of the river basin and the depth of the sample is from surface to one meter depth collected by augur boring method. The total number of the samples is 30 . The samples are combined to prepare the head sample for physical separation test. Mineralogical factors which are generally considered important in mineral processing are identify (crystal structure and chemistry) and proportion of minerals, textural associations, variability in composition and particle size, shape and distribution with regards to individual minerals and in the bulk sample (Jain, 2001). A single characterization technique is generally not sufficient. In the present study, the grain size analysis of bulk sediment by sieve analyzer, the heavy mineral concentration is determined by heavy liquid separation (Bromoform sp. 2.89). The mineralogical studies of heavy fractions were carried out following the method of Mange and Maurer (Mange and Maurer, 1991) by polarizing and reflected microscopes, the elemental analyses by X-ray fluorescence spectrophotometer (XRF) (Goto, A. et.al, 1994 \& 1996) have been carried out. The feasibility of physical separation by shaking table, Induced Roll magnetic Separator (IRMS) and electrostatic plate separator (ESPS) have been performed on the heavy fractions to develop a physical separation method to separate and upgrade the concentration of individual mineral from the Someswari River sands.

\section{Results and discussion}

Grain size analysis

The grain size distribution of the bulk sediment is given in Table I. The grain size distribution of the Someswari River sands shows that the highest percentage of size is retained in the fraction $500 \mu \mathrm{m}-1 \mathrm{~mm}(65.18 \%)$. The variation of the grain size distribution depends on the distance between source and deposited area. The grain size distribution is very much important for and has impact on the separation of heavy minerals. From the previous research, it is understood that the individual mineral is liberated well in the size fraction less than $250 \mu \mathrm{m}$.

\section{Mineralogical study}

The heavy mineral concentration of Someswari River is $4.03 \%$ determined by heavy-liquid separation method. The heavy concentration is low compared to beach sand or other river sands of Bangladesh because of the grain size

\section{Table I. The average grain size distribution of sands of} the Someswari River (\%).

\begin{tabular}{cc}
\hline Mesh size & Bulk Sands of the some wari River \\
\hline$>2 \mathrm{~mm}$ & 0 \\
$1 \mathrm{~mm}-2 \mathrm{~mm}$ & 0 \\
$500 \mu \mathrm{m}-1 \mathrm{~mm}$ & 65.18 \\
$250 \mu \mathrm{m}-500 \mu \mathrm{m}$ & 29.20 \\
$125 \mu \mathrm{m}-250 \mu \mathrm{m}$ & 4.99 \\
$63 \mu \mathrm{m}-125 \mu \mathrm{m}$ & 0.22 \\
$45 \mu \mathrm{m}-63 \mu \mathrm{m}$ & 0.08 \\
Pan & 0.13 \\
\hline
\end{tabular}

distribution, the maximum content of grain is in the size fraction $500 \mu \mathrm{m}-1 \mathrm{~mm}(65.18 \%)$ and the heavy minerals cannot be well liberated in this size fraction.

The percentage of valuable heavy minerals in the heavy concentration of the Someswari River sands is given in Table II. Though the concentration of total heavy mineral of Someswari River is low but the individual mineral concentration is notably high for further physical separation. The highest concentrated mineral is magnetite $(8.44 \%)$ followed by ilmenite $(2.34 \%)$, garnet $(1.96 \%)$, zircon $(0.78 \%)$ and rutile $(0.51 \%)$ are counted in the heavy fraction of Someswari River sands. 


\section{Elemental analysis}

It is essential to know the elemental composition of bulk sediment before mineral processing study. From the study of

Table II. The percentage of valuable heavy minerals in the heavy concentration.

\begin{tabular}{c|c}
\hline $\begin{array}{c}\text { Mineral } \\
\text { Name }\end{array}$ & Heavy Fractions of the bulk sands \\
\hline Garnet & 1.96 \\
Ilmenite & 2.34 \\
Magnetite & 8.44 \\
Rutile & 0.51 \\
Zircon & 0.78 \\
\hline
\end{tabular}

elemental composition of the sample, the prospective sample can be identified for mineral processing. The elemental composition of bulk sands of the Someswari River is given in Table III. The silicon-di oxide $\left(\mathrm{SiO}_{2}\right)$ content $(81.89 \%)$ is high but aluminum oxide $\left(\mathrm{Al}_{2} \mathrm{O}_{3}\right)$, sodium oxide $\left(\mathrm{Na}_{2} \mathrm{O}\right)$ and magnesium oxide $(\mathrm{MgO})$ is low in the Someswari river sands. From the mineralogical study it is identified a relationship that the content of feldspar is low (1-2\%) and as well as the ferromagnesian minerals in the Someswari river sands and for this reason the higher silica percentage and lower aluminum, sodium and magnesium oxide content in the bulk sands of the Someswari River. It is also understood from this study that this sand is prospective for glass making sand

Table III. The percentage of elemental composition of bulk sand.

\begin{tabular}{|c|c|}
\hline Element & Bulk Sands of the Someswari River \\
\hline $\mathrm{Na}_{2} \mathrm{O}$ & 0.82 \\
\hline $\mathrm{MgO}$ & 0.57 \\
\hline $\mathrm{Al}_{2} \mathrm{O}_{3}$ & 7.24 \\
\hline $\mathrm{SiO}_{2}$ & 81.89 \\
\hline $\mathrm{P}_{2} \mathrm{O}_{5}$ & 0.05 \\
\hline $\mathrm{SO}_{3}$ & 0.08 \\
\hline $\mathrm{Cl}$ & 0.08 \\
\hline $\mathrm{K}_{2} \mathrm{O}$ & 2.52 \\
\hline $\mathrm{CaO}$ & 0.72 \\
\hline $\mathrm{Ti}_{2} \mathrm{O}$ & 0.33 \\
\hline $\mathrm{Cr}_{2} \mathrm{O}_{3}$ & 0.55 \\
\hline $\mathrm{MnO}$ & 0.06 \\
\hline $\mathrm{Fe}_{2} \mathrm{O}_{3}$ & 4.98 \\
\hline $\mathrm{NiO}$ & 0.03 \\
\hline $\mathrm{Rb}_{2} \mathrm{O}$ & 0.01 \\
\hline SrO & 0.01 \\
\hline $\mathrm{Zr}_{2} \mathrm{O}$ & 0.02 \\
\hline $\mathrm{BaO}$ & 0.04 \\
\hline
\end{tabular}

(Silica Sand) after separation of heavy mineral by physical separation method. It is also observed that the iron oxide $\left(\mathrm{Fe}_{2} \mathrm{O}_{3}\right)$ content $(4.98 \%)$ of the Someswari River sands is high due to abundance of magnetite mineral.

\section{Feasibility of Physical Separation}

Like the beach sands, the river sands could be a major global resources for the industrial minerals like quartz $\left(\mathrm{SiO}_{2}\right)$, rutile $\left(\mathrm{TiO}_{2}\right)$, ilmenite $\left(\mathrm{FeTiO}_{3}\right)$, zircon $\left(\mathrm{ZrSiO}_{4}\right)$ etc. After mining, concentration of heavy minerals from beach/river sands typically involves a gravitational separation process and/or flotation, resulting in a heavy mineral concentrate (HMC). Magnetic separation processes may produce two distinct fractions. The magnetic fraction is enriched in Fe-bearing minerals, such as ilmenite. The non-magnetic fraction is enriched in Fe-poor minerals, including rutile and zircon. Differences in the conductive properties of rutile (conductive) and zircon (non-conductive) allow them to be subsequently separated electro-statically (Fig.2).

The discharge process is governed by the surface electrostatic properties, therefore mineralogy, surface coatings, inclusions and surface geometry may all affect the separation process. Determining the chemical and physical properties of these concentrates is therefore important to optimize this separation process and to maintain its efficiency. The separation tests were performed on the bulk samples of the Someswari River. The result of the feasibility of physical separation by gravity, magnetic and electrostatic test is presented in Fig. 3.

\section{Gravity Separation by Shaking Table}

At first the gravity separation test was performed by wilfly shaking table on the head samples of Someswari River. The products from gravity separation are heavy fraction and light fraction. From this study, it is noticed that the silicon-di oxide $\left(\mathrm{SiO}_{2}\right)$ content is decreased in heavy fractions and increased in light fractions whereas other titanium oxide $\left(\mathrm{TiO}_{2}\right)$, iron oxide $\left(\mathrm{Fe}_{2} \mathrm{O}_{3}\right)$, zirconium oxide $\left(\mathrm{ZrO}_{2}\right)$ content are increased in heavy fraction and decreased in light fraction (Fig. 3). It is also note that the iron oxide $\left(\mathrm{Fe}_{2} \mathrm{O}_{3}\right)$ content in light fraction of the Someswari River is little decrease because the light mineral quartz (silica) of the Someswari River sands is coated with iron oxide. As a result, though quartz (silica) is light mineral but found more in heavy fraction of the Someswari River sands due to iron oxide coating and less liberation (near source area) than any other river sand in Bangladesh. This gravity separation technique is less effective on someswari river sand.

\section{Magnetic Separation by Induced Roll Magnetic Separator (IRMS)}

After gravity separation the heavy fractions of Someswari 


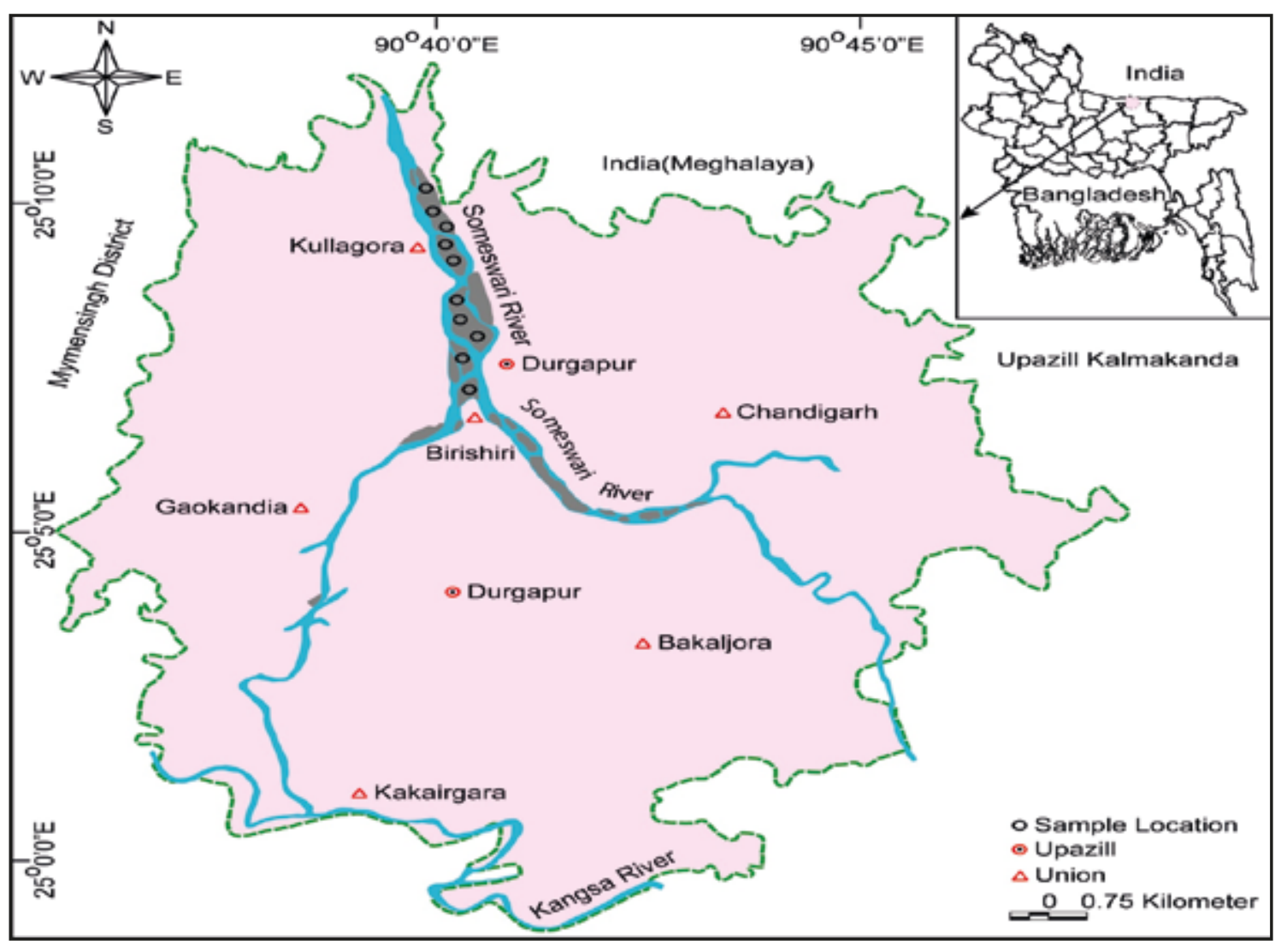

Fig. 1. Location map of the Someswari River.

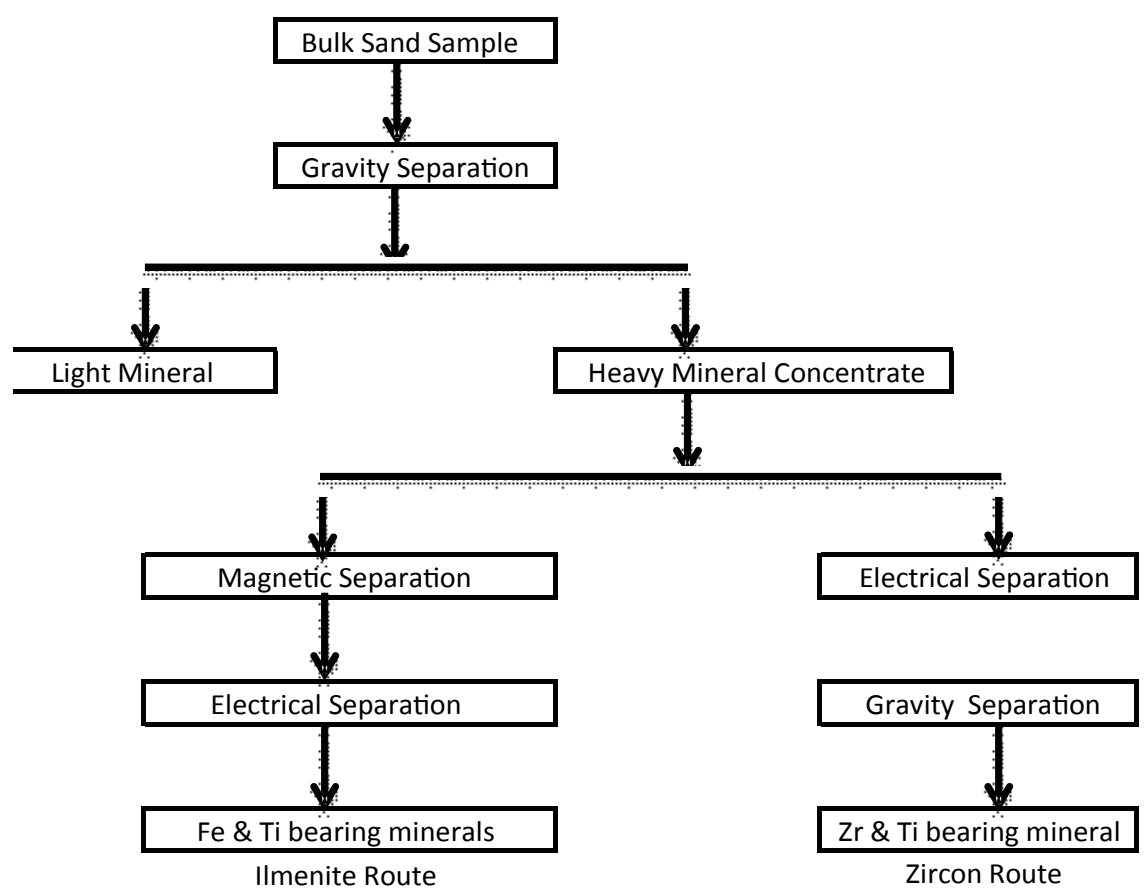

Fig. 2. Typical flow sheet of physical separation method for heavy mineral separation 


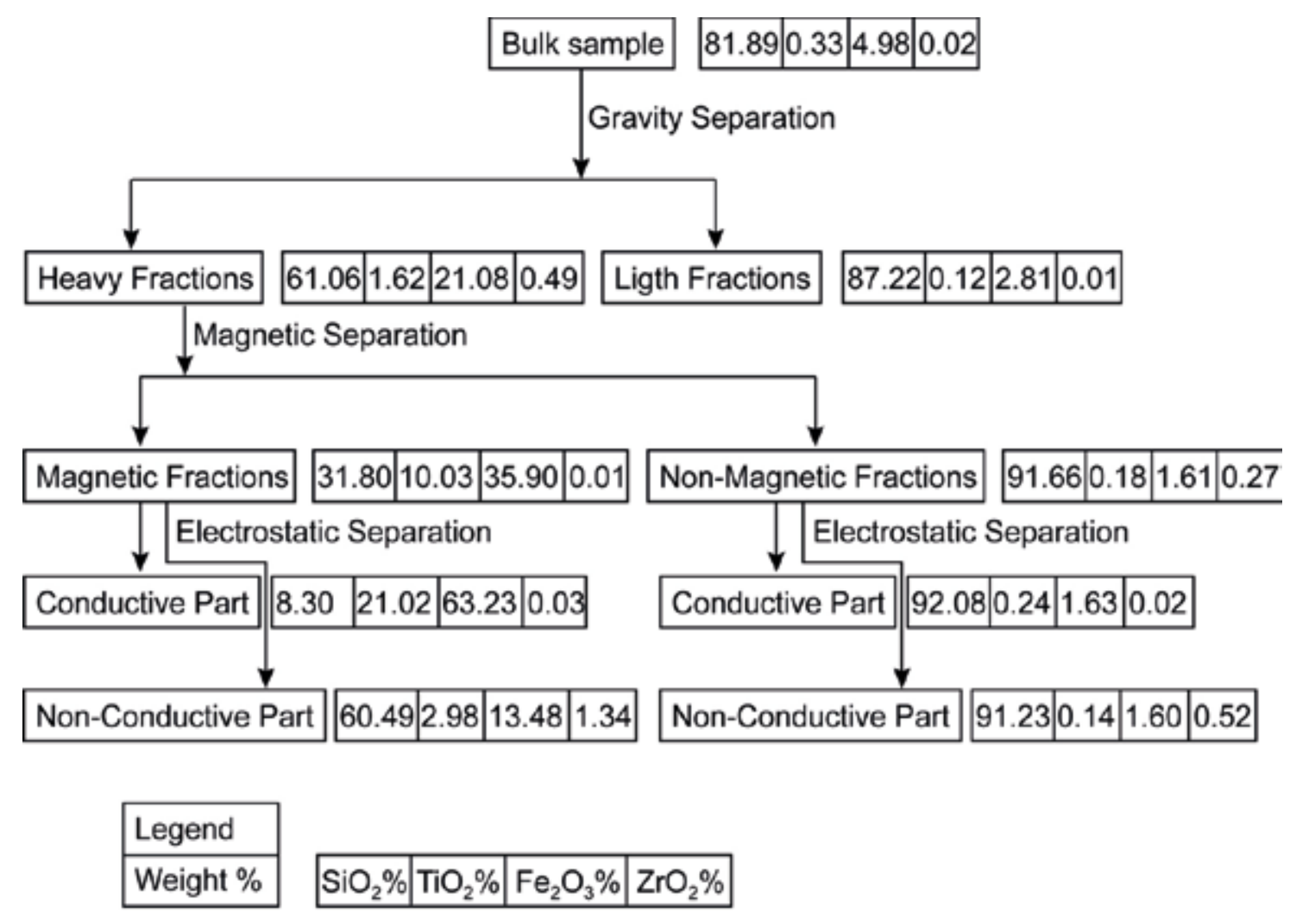

Fig. 3. Schematic diagram of feasibility for physical separation test performed on the bulk sands of the Someswari River

River sands is run into the induced roll magnetic separator to separate the magnetic and non-magnetic fractions. It is observed that the silicon-di oxide $\left(\mathrm{SiO}_{2}\right)$ content is significantly degraded in the magnetic fraction and upgraded in nonmagnetic fraction (Fig. 3). It is also observed that the silicon-di oxide $\left(\mathrm{SiO}_{2}\right)$ content in nonmagnetic fraction of the Someswari River sands is high which can be potential for glass production. On the other hand, titanium oxide $\left(\mathrm{TiO}_{2}\right)$ and iron oxide $\left(\mathrm{Fe}_{2} \mathrm{O}_{3}\right)$ are increased in the heavy fractions and decreased in the nonmagnetic fraction. A little change is found in zirconium oxide $\left(\mathrm{ZrO}_{2}\right)$ content in both fractions. It is also revealed that there is no need of primary gravity separation for someswari river sand and the raw sand can be easily separated into magnetic and non-magnetic parts.

\section{Electrostatic separation by Electrostatic Plate separator} (ESPS)

The magnetic and nonmagnetic fractions are run through the electrostatic plate separator to separate the conductive and nonconductive minerals from the fractions. From the result of the test, it is shown that the upgradation of titanium oxide $\left(\mathrm{TiO}_{2}\right)$ and iron oxide $\left(\mathrm{Fe}_{2} \mathrm{O}_{3}\right)$ are continuing in the conductive part and degradation is continuing in the nonconductive part of magnetic fractions (Fig. 3). On the other hand the concentration of all oxide remains more or less same except zirconium oxide $\left(\mathrm{ZrO}_{2}\right)$ after electrical separation of nonmagnetic fraction. Due to less abundance of other silicates minerals like amphibole, pyroxene and other aluminum silicates minerals than any other river sand, the ilmenite can be efficiently cleaned from zircon and other minerals through this separation technique.

\section{Conclusion}

The main objective of the study is to conduct physical separation test for upgradation of heavy mineral concentrate of the Someswari River. From beneficiation test by physical separation method it is observed that sands of the Someswari River are prospective for quartz (silica percentage upgrade upto about 93\%) and magnetic minerals magnetite, ilmenite 
and garnet which were separated efficiently by magnetic separator. After separation of heavy minerals from the bulk sand and further treatment of the light mineral quartz can be used as glass sand. The huge amount of sediment is deposited in the Someswari River basin in every year. Magnetite can be easily separated by hand magnet which can be done by local people. There are two common routes in mineral separation plant, one is ilmenite route and another is zircon route (Fig.2). The other $\mathrm{Fe}$ and Ti bearing minerals ilmenite and garnet can be separated in the ilmenite route of Physical separation flow sheet. As a result the only ilmenite route will be required to separate the heavy minerals from the Someswari river sand which would be cost effective because of less separation equipments to be used.

The mineral processing industry could be developed in our country. The processed mineral could be exported in other countries (e.g. Japan, U.S.A, Germany, Italy etc.) and used in our local industries. Therefore, employment opportunity could be created in our country and a way to earn foreign currency. The identified heavy minerals and light minerasl of the river can be separated through mineral processing method and these minerals could be utilized in different industries like paint, ceramics, glass, leather, shipbuilding industries etc. Thus the under mentioned activities can be achieved from the present study:

- The huge quantity of sandy materials of the rivers will be utilized as mineral sands.

- The mineral sands would be refined as commercial and industrial grade for industrial uses.

- The heavy minerals and light minerals of the river sand can be separated through mineral processing method.

- These separated minerals will be utilized in different industries like paint, ceramics, glass, leather, shipbuilding industries etc.

\section{Acknowledgement}

The authorities of BCSIR are highly acknowledged for providing research grant for this present work. The authors are also thankful to the Director, other scientists, technicians and laboratory attendants of this institute for their help during field work, sample preparation and analytical services.

\section{References}

Anomymous, (1991) Mineral Sands in Asia and the Pacific Economic and Social Commission or Asia and the Pacific, 4: 1.

Elder J., and Kow W. (2005) The new mineral sands plant of the $3^{\text {rd }}$ Millennium...How difficult-to-treat feedstocks can get a new lease on life. Heavy Minerals 2005, 16-19 Oct., Society for Mining, Metallurgy and Exploration. Littleton, Colorado: 2005. p. 127-131.

Elder J. (2006) Physical Separation of minerals: Developments and trends. 18th Industrial Minerals International Congress and Exhibition, , March 26-29, San Francisco, USA.

Goto, A. and Tatsumi, Y. (1994). Quantitative analysis of rock samples by an X-ray fluorescence spectrometer (I). The Rigaku Journal, 11: 40-59.

Goto, A. and Tatsumi, Y. (1996). Quantitative analysis of rock samples by an X-ray fluorescence spectrometer (II). The Rigaku Journal, 13(2): 20-39.

Jain S.K. (2001) Mineral Processing, $2^{\text {nd }}$ Edition, CBS Publishers \& Distributors, p. 518.

Mange A. M., and Maurer H. E. W. (1991) Schwerminerale in Farbe, Ferdinand Enke Verlag Stuttgart, Germany, p. 148.

Received: 13 March 2014; Revised: 27 November 2014;

Accepted: 22 December 2014. 